(c) American Dairy Science Association, 2003.

\title{
Modeling Extended Lactation Curves of Dairy Cattle: A Biological Basis for the Multiphasic Approach ${ }^{1}$
}

\author{
M. Grossman ${ }^{*} \boldsymbol{\dagger}^{, 2}$ and W. J. Koopsł \\ *Department of Animal Sciences, University of Illinois, Urbana 61801, U.S.A. \\ †Department of Statistics, University of Illinois, Champaign 61820, U.S.A. \\ $\ddagger$ Animal Production Systems Group, Wageningen Institute of Animal Sciences, \\ Wageningen University, PO Box 338, 6700 AH Wageningen, The Netherlands
}

\begin{abstract}
Objectives of this study are to describe the biological basis for multiphasic milk production and to propose a new empirical model for the lactation curve. To illustrate this model, we used data on 3573 first-lactation Holsteins having lactations of various lengths $(285,345$, $405,465$, and $525 \mathrm{~d})$ and with various days open (45, $105,165,225$, and $285 \mathrm{~d}$ ).

The model describes an increasing first phase of milk yield and a series of decreasing phases of yield. The increasing phase, described by an increasing logistic function of time, is associated with increase in number of active mammary gland cells and increase in yield per cell. The decreasing phases, described by three decreasing logistic functions of time, are associated with decreases in cell number due to apoptosis and in yield per cell due to pregnancy. The new model is

$$
\begin{aligned}
& \mathrm{y}_{\mathrm{DIM}}=\frac{\mathrm{a}_{1}}{1+\mathrm{e}^{-\left(\mathrm{DIM}-\mathrm{c}_{1}\right) / \mathrm{b}_{1}}}-\frac{\mathrm{p}_{2} \mathrm{a}_{1}}{1+\left(0.5 \mathrm{e}^{\left.-\left(\mathrm{DIM}-\mathrm{c}_{\max 2}\right) / \mathrm{b}_{2}\right)^{2}}\right.} \\
& -\frac{\mathrm{p}_{3} \mathrm{a}_{1}}{1+\mathrm{e}^{-\left(\mathrm{DIM}-\mathrm{c}_{3}\right) / \mathrm{b}_{3}}}-\frac{\mathrm{p}_{4} \mathrm{a}_{1}}{\left(1+0.5 \mathrm{e}^{\left.-\left(\mathrm{DIM}-\mathrm{c}_{\max 4}\right) / \mathrm{b}_{4}\right)^{2}}\right.}
\end{aligned}
$$

where $\mathrm{y}_{\text {DIM }}$ is milk yield at each day in milk (DIM), $\mathrm{a}_{1}$ is upper level for the increasing first phase, and $\mathrm{p}_{2}, \mathrm{p}_{3}$, and $\mathrm{p}_{4}=\left(1-\mathrm{p}_{2}-\mathrm{p}_{3}\right)$ are proportions of $\mathrm{a}_{1}$ for the decreasing second, third, and fourth phases; b's are proportional to duration of each phase; and c's are time of maximum increase or decrease. Nonlinear regression was used to fit average milk yield for each of nine datasets, four with $180 \mathrm{~d}$ carried calf and five with $240 \mathrm{~d}$ carried calf.

Average results indicated that for the first phase, upper level of milk yield was about $22 \mathrm{~kg}$. Duration

\footnotetext{
Received August 15, 2001.

Accepted March 15, 2002.

${ }^{1}$ Supported in part by University of Illinois Agricultural Experiment Station, Hatch Project ILLU-35-0339.

${ }^{2}$ Address correspondence to Michael Grossman, 1207 W. Gregory Drive, Urbana, IL 61801, U.S.A., or e-mail: mikeg@uiuc.edu.
}

was about $120 \mathrm{~d}$, centered on time of maximum increase, which was about $11 \mathrm{~d}$ before calving. For the second phase (first phase of apoptosis), decrease in yield was relatively large (about 20\%) and duration was relatively long (about $375 \mathrm{~d}$ ). Time of maximum decrease was about $107 \mathrm{~d}$ after calving. For the third phase (pregnancy), decrease in yield was relatively small (about $6 \%$ ) and duration was relatively short (about $200 \mathrm{~d}$ ). Time of maximum decrease was about $300 \mathrm{~d}$ after calving. For each additional day open, time of maximum decrease increased about $1 \mathrm{~d}$. For the fourth phase (second phase of apoptosis), decrease in yield was relatively large (about 74\%) and duration was relatively long (about $765 \mathrm{~d}$ ). Duration for the lactation length of 525 d was exceptionally long. Time of maximum decrease was about $382 \mathrm{~d}$ after calving. For each additional day of lactation, duration increased about $5.4 \mathrm{~d}$ and day of maximum decrease increased about $0.82 \mathrm{~d}$.

We believe that it is possible to model empirically standard and extended lactation curves of dairy cows, based on biological theory and predicated on the multiphasic approach. Further research to understand better the biology of extended lactations, using the proposed multiphasic model, should use planned extended lactations that are at least $525 \mathrm{~d}$ in milk and have at least $240 \mathrm{~d}$ carried calf.

(Key words: multiphasic lactation curve model, extended lactation, pregnancy, apoptosis)

Abbreviation key: DCC = days carried calf while milking, $\mathbf{D O}=$ days open, $\mathbf{D}-\mathbf{W}=$ Durbin-Watson statistic, $\mathbf{L L}=$ lactation length.

\section{INTRODUCTION}

The possibility of extending lactations has received attention as an alternative to maximizing peak yield and minimizing calving interval (Knight, 1997, 1998; Knight and Sorensen, 2000). Extending lactations can be accomplished by planned increase in calving interval (Bertilsson et al., 1997), for example, and by use of bovine somatotropin to increase daily yield (van Amburgh et al., 1997). Expected benefits of extended lacta- 
tions, defined as calving every 18 mo or more, might include reduction in number of excess progeny, in insemination costs, and in number of days dry within the cow's lifetime (FAWC, 1997). For animal well-being, in addition, there could be benefits in reduced metabolic stress, in exposure to fewer periods of high risk, and in increased longevity (FAWC, 1997; Knight, 1998).

Extending the lactation, however, has its problems for high-yielding dairy cows. It is sometimes difficult to get cows pregnant at the desired time (i.e., 9 mo after calving), for example, and some cows become too fat and perform unsatisfactorily in later lactations. Nevertheless, one approach to extending the lactation is to alter the shape of the lactation curve to produce flatter, more persistent, prolonged lactations (FAWC, 1997). There are two approaches to change the shape of the lactation curve, either by genetic selection or by management strategies. Each approach, however, requires understanding the biological processes that determine the shape of the curve.

It might be said that there are as many models for the lactation curve of dairy animals (e.g., cattle, sheep, and goats) as there are authors of them. Models for lactation curves fall, generally, into two categories: mechanistic models, based on the biology of lactation (e.g., mammary gland growth and regression, or nutrient flow), and empirical models, based on actual milkyield data (e.g., test-day data). Examples of mechanistic models include those of Neal and Thornley (1983), Oldham and Emmans (1989), Dijkstra et al. (1997), and Pollott (2000) for dairy cows; and Knight and Peaker (1984) for goats. Examples of empirical models include those of Wood (1967), Grossman and Koops (1988), and Grossman et al. (1999) for dairy cows; Pollott and Gootwine (2000) and Ruiz et al. (2000) for sheep; and Gipson and Grossman $(1989,1990)$ for goats. [For a review of mechanistic and empirical models for the lactation curve of dairy cows, see Beever et al. (1991).]

A comparison of nine empirical models for lactation curves of dairy cows from Costa Rica was conducted on standard 305-d lactations and on unplanned extended lactations that varied in length and in interval from calving to conception (Vargas et al., 2000). The best models were the diphasic model (Grossman and Koops, 1988) and the lactation persistency model (Grossman et al., 1999). None of the models, however, described extended lactations satisfactorily because of poor fit, failure to converge, or poor interpretability of parameters. Models suitable to describe standard 305-d lactations, furthermore, were not necessarily best to describe extended lactations. A mathematical model to describe the extended lactation, therefore, needs to be developed.

The multiphasic approach to empirical modeling of the lactation curve in dairy cattle was introduced first by Grossman and Koops (1988), who used multiple logistic functions. The multiphasic model also has been used successfully to model milk yield in goats (Gipson and Grossman, 1989) and to model milk and fat production in cows (de Boer et al., 1989). The multiphasic model compared well with other lactation models for sheep (Pollott and Gootwine, 2000) and for cows (Sherchand et al., 1995; Vargas et al., 2000). One criticism of the multiphasic model, however, has been that it lacks a biological basis (Beever et al., 1991; Rook et al., 1993; Williams, 1993; Tozer and Huffaker, 1999). We believe, of course, that this criticism is unwarranted.

Objectives of this study are to describe the biological basis for multiphasic milk production and to propose a new empirical model for the lactation curve, based on the biological theory and predicated on the multiphasic approach for use with standard and extended lactations. To illustrate this model, we used data on lactations of various lengths and with various days open (Vargas et al., 2000).

\section{MATERIALS AND METHODS}

\section{Biological Basis for Multiphasic Approach}

The lactation curve of the dairy cow, although quantitatively different from, is qualitatively similar to that of the dairy goat. In the dairy cow, the lactation curve describes milk yield that starts at parturition, rises rapidly to a peak between 3 and $6 \mathrm{wk}$, maintains that level for several weeks, and finally declines until the end of lactation (Schmidt, 1971). In the dairy goat (Knight and Wilde, 1987), increase in milk yield during the first $3 \mathrm{wk}$ of lactation is associated with increase in cell number. From about 3 to 8 wk, there is an increase in milk yield but no increase in cell number; hence, yield per cell increases. After peak lactation (from about 8 to $23 \mathrm{wk}$ ), however, there is a decrease in milk yield and in cell number. During late lactation (from about 23 to $36 \mathrm{wk}$ ) and pregnancy, milk yield continues to fall but cell number is maintained; hence, yield per cell decreases.

The lactation curve, with its increase and decrease in milk yield, is associated with periods of growth and regression of the mammary gland. Growth of the mammary gland and consequent increase in milk yield is the net result of increase in number of mammary secretory cells during gestation and early lactation and of increase in rate of secretion of mammary gland tissue (Terranova and Taylor, 1999). Regression of the mammary gland and consequent decrease in milk yield, however, is the net result of decrease in number of mammary cells from cell death, or apoptosis (Wilde and Knight, 1989; Wilde et al., 1997; Wareski et al., 2001), and of decrease in rate of secretion from specific hor- 
monal signals during pregnancy (Forsyth, 1999). These phases of mammary gland growth and regression, brought about by proliferation, apoptosis, and pregnancy, provide the biological basis for our multiphasic approach to modeling the lactation curve.

\section{General Lactation Model}

The point of departure for our development will be the multiphasic lactation model, specifically the diphasic logistic model (Grossman and Koops, 1988). A logistic cumulative distribution function of time $t$ is a symmetric, sigmoid-shaped curve for $-\infty<t<+\infty$, which first increases at an increasing rate from a lower asymptote of zero at $t=-\infty$ to half the upper asymptote $1 / 2 \mathrm{~A}$ at the point of inflection c, or time of maximum increase, and then increases at a decreasing rate from $1 / 2 \mathrm{~A}$ at $\mathrm{c}$ to the upper asymptote $\mathrm{A}$ at $\mathrm{t}=+\infty$ :

$$
\frac{\mathrm{A}}{1+\mathrm{e}^{-(\mathrm{t}-\mathrm{c}) / \mathrm{b}}}
$$

where b is proportional to the "duration" of the distribution and $\mathrm{e}$ is the base of the natural logarithm. Mean of the distribution is $\mu=\mathrm{c}$ and variance is $\sigma^{2}=\pi^{2} \mathrm{~b}^{2} / 3(\sigma$ $=\pi \mathrm{b} / \sqrt{3})$ (Gupta and Gnanadesikan, 1966). The logistic distribution approximates the normal distribution (Bock, 1975), so we assumed that $\mathrm{c}-3 \sigma$ to $\mathrm{c}+3 \sigma$ contains about $99 \%$ of the logistic distribution centered on c; hence $6 \sigma=6 \pi \mathrm{b} / \sqrt{ } 3=10.88 \mathrm{~b}$ contains about $99 \%$ of the distribution. The duration of the logistic distribution, therefore, means that about $99 \%$ of the distribution is $10.88 b$, from $c-1 / 2(10.88) b$ to $c+1 / 2(10.88) b$, centered on $\mathrm{c}$.

The diphasic logistic model for the lactation curve (Grossman and Koops, 1988), however, was based on the logistic probability density function, or first derivative of the logistic cumulative distribution function with respect to $t$, parameterized in terms of the hyperbolic tangent function. The logistic probability density function will be given here, however, in a reparameterized form for clarity and convenience, but with the same parameters as in Equation [1]:

$$
\left(\frac{A}{b}\right)\left(\frac{1}{1+e^{-(t-c) / b}}\right)\left(\frac{1}{1+e^{(t-c) / b}}\right)
$$

The third term in Equation [2] can be rewritten to yield:

$$
\left(\frac{\mathrm{A}}{\mathrm{b}}\right)\left(\frac{1}{1+\mathrm{e}^{-(\mathrm{t}-\mathrm{c}) / \mathrm{b}}}\right)\left(1-\frac{1}{1+\mathrm{e}^{-(\mathrm{t}-\mathrm{c}) / \mathrm{b}}}\right),
$$

so that when Equation [3] is expanded it yields a secondorder polynomial in the logistic function:

$$
\left(\frac{\mathrm{A}}{\mathrm{b}}\right)\left(\frac{1}{1+\mathrm{e}^{-(\mathrm{t}-\mathrm{c}) / \mathrm{b}}}-\frac{1}{\left(1+\mathrm{e}^{-(\mathrm{t}-\mathrm{c}) / \mathrm{b}}\right)^{2}}\right) .
$$

We will refer to the second term of Equation [4] as a (symmetric) linear logistic function, associated with increase in milk yield, and to the third term as a (asymmetric) quadratic logistic function, associated with decrease in milk yield.

To describe the lactation curve using a diphasic logistic model, we expressed the model as a sum of two linear and two quadratic logistic functions of time $t$ based on the polynomial in Equation [4]:

$$
\begin{aligned}
& a_{1}\left(\frac{1}{1+\mathrm{e}^{-\left(\mathrm{t}-\mathrm{c}_{1}\right) / b_{1}}}-\frac{1}{\left(1+\mathrm{e}^{\left.-\left(\mathrm{t}-\mathrm{c}_{1}\right) / b_{1}\right)^{2}}\right.}\right) \\
+ & \mathrm{a}_{2}\left(\frac{1}{1+\mathrm{e}^{-\left(\mathrm{t}-\mathrm{c}_{2}\right) / \mathrm{b}_{2}}}-\frac{1}{\left(1+\mathrm{e}^{\left.-\left(\mathrm{t}-\mathrm{c}_{2}\right) / \mathrm{b}_{2}\right)^{2}}\right.}\right),
\end{aligned}
$$

where subscript 1 denotes parameters of the first phase and subscript 2 denotes parameters of the second. For the linear and quadratic functions taken together, therefore, $a_{1}$ is the upper asymptotic level for the first phase and $a_{2}$ is for the second, $b_{1}$ is proportional to duration of the first phase and $b_{2}$ is of the second, and $c_{1}$ is time of maximum increase for the first phase and $c_{2}$ is for the second.

To allow more flexibility for each phase of the lactation curve, we expressed the model as a sum of four logistic-type functions, based on the two polynomials in Equation [5], each function with different parameters:

$$
\begin{gathered}
\frac{\mathrm{a}_{1}}{1+\mathrm{e}^{-\left(\mathrm{t}-\mathrm{c}_{1}\right) / \mathrm{b}_{1}}}-\frac{\mathrm{a}_{2}}{\left(1+\mathrm{e}^{-\left(\mathrm{t}-\mathrm{c}_{2}\right) / \mathrm{b}_{2}}\right)^{2}} \\
-\frac{-\mathrm{a}_{3}}{1+\mathrm{e}^{-\left(\mathrm{t}-\mathrm{c}_{3}\right) / \mathrm{b}_{3}}}-\frac{\mathrm{a}_{4}}{\left(1+\mathrm{e}^{\left.-\left(\mathrm{t}-\mathrm{c}_{4}\right) / \mathrm{b}_{4}\right)^{2}}\right.},
\end{gathered}
$$

where $a_{1}$ is still the upper level, or amount of increase, for the increasing (first) phase, and now $\mathrm{a}_{2},-\mathrm{a}_{3}$, and $\mathrm{a}_{4}$ are amounts of decrease for the decreasing (second, third, and fourth) phases; $b_{1}$ is still proportional to duration of the increasing (first) phase, and now $b_{2}, b_{3}$, and $b_{4}$ are proportional to durations of the decreasing (second, third, and fourth) phases; and $c_{1}$ is still time of maximum increase for the increasing (first) phase and $c_{3}$ is now time of maximum decrease for the decreasing (third) phase. [Definitions for $c_{2}$ and $c_{4}$ will be given below.]

Preliminary analyses (not shown) indicated that parameter $a_{3}$ was estimated generally as a negative value, so $-\mathrm{a}_{3}$ in Equation [6] was replaced by $\mathrm{a}_{3}$. In addition, 
the upper level for the first phase $\left(a_{1}\right)$ differs by lactation, so that it would be useful to express the decrease for the decreasing phases not as an absolute amount $\left(\mathrm{a}_{2}, \mathrm{a}_{3}\right.$, and $\left.\mathrm{a}_{4}\right)$ but rather as a proportion of $\mathrm{a}_{1}$. Thus we let $\mathrm{a}_{2}=\mathrm{p}_{2} \mathrm{a}_{1}, \mathrm{a}_{3}=\mathrm{p}_{3} \mathrm{a}_{1}$, and $\mathrm{a}_{4}=\mathrm{p}_{4} \mathrm{a}_{1}$, where $\mathrm{p}_{2}$ is the proportionally constant for the second phase, $p_{3}$ is for the third phase, and $\mathrm{p}_{4}$ is for the fourth phase.

Parameter $c_{1}$ or $c_{3}$ can be interpreted as time of maximum increase $\left(c_{1}\right)$ or decrease $\left(c_{3}\right)$, because each parameter is contained in the linear logistic function. Parameter $\mathrm{c}_{2}$ or $\mathrm{c}_{4}$, however, cannot be interpreted as time of maximum decrease, because each parameter is contained in the quadratic logistic function. Each quadratic function, therefore, was reparameterized to include time of maximum decrease $\left(c_{\max }\right)$ by taking the second derivative with respect to $t$, setting it equal to zero, and solving for $\mathrm{c}_{\max }$. For the first quadratic function, $\mathrm{c}_{\max 2}$ $=c_{2}+b_{2} \operatorname{Ln}(2)$, and for the second quadratic function, $c_{\max 4}=c_{4}+b_{4} \operatorname{Ln}(2)$, where $\operatorname{Ln}(2)$ is the natural logarithm of 2. Substituting $c_{\max 2}-b_{2} \operatorname{Ln}(2)$ for $c_{2}$ and $c_{\max 4}$ $-b_{4} \operatorname{Ln}(2)$ for $c_{4}$ in Equation [6] yielded, after simplification:

$$
\begin{gathered}
\frac{\mathrm{a}_{1}}{1+\mathrm{e}^{-\left(\mathrm{t}-\mathrm{c}_{1}\right) / \mathrm{b}_{1}}}-\frac{\mathrm{p}_{2} \mathrm{a}_{1}}{\left(1+0.5 \mathrm{e}^{-\left(\mathrm{t}-\mathrm{c}_{\max 2} / \mathrm{b}_{2}\right)^{2}}\right.} \\
-\frac{\mathrm{p}_{3} \mathrm{a}_{1}}{1+\mathrm{e}^{-\left(\mathrm{t}-\mathrm{c}_{3}\right) / \mathrm{b}_{3}}}-\frac{\mathrm{p}_{4} \mathrm{a}_{1}}{\left(1+0.5 \mathrm{e}^{\left.-\left(\mathrm{t}-\mathrm{c}_{\max }\right) / \mathrm{b}_{4}\right)^{2}}\right.} .
\end{gathered}
$$

The $b_{2}$ and $b_{4}$ were not reparameterized, however, because they were assumed to have the same relation to $\sigma$ in the quadratic logistic function as $\mathrm{b}_{1}$ and $\mathrm{b}_{3}$ have in the linear logistic function.

At $t=+\infty$, Equation [7] reduces to $a_{1}-p_{2} a_{1}-p_{3} a_{1}$ $-p_{4} a_{1}=a_{1}\left(1-p_{2}-p_{3}-p_{4}\right)$, which must equal zero in practice because the cow eventually dries off. If $\left(1-p_{2}\right.$ $\left.-p_{3}-p_{4}\right)=0$, then for the purpose of estimation we must replace $p_{4}$ with $\left(1-p_{2}-p_{3}\right)$, because there are only two independent parameters among the three.

Note that a symmetric linear logistic function-for example, the first or third term of Equation [7] - is proportional to $a_{1} / 2$ through the proportionality constant 1 or $p_{3}$ when $t=c_{1}$ or $c_{3}$, whereas an asymmetric quadratic logistic function-for example, the second or fourth term-is proportional to $4 \mathrm{a}_{1} / 9$ through the proportionality constant $\mathrm{p}_{2}$ or $\mathrm{p}_{4}$ when $\mathrm{t}=\mathrm{c}_{\max 2}$ or $\mathrm{c}_{\max 4}$. For the symmetric linear function, therefore, half $(0.5)$ the upper level is reached at the point of inflection $\left(c_{1}\right.$ or $c_{3}$ ), and the remaining half (0.5) is reached after the point of inflection. For the asymmetric quadratic function, however, less than half (0.44) the upper level is reached at the point of inflection $\left(c_{\max 2}\right.$ or $\left.c_{\max 4}\right)$, and the remaining more than half $(0.56)$ is reached after the point of inflection.



Figure 1. A typical lactation curve (-) represented by a multiphasic model. The $a_{1}$ is the upper level for the increasing first phase (- - ), and $\mathrm{a}_{2}, \mathrm{a}_{3}$, and 0 are lower levels for the decreasing second (-- ), third (-- ), and fourth (- - -) phase; $\mathrm{p}_{2}, \mathrm{p}_{3}$, and $\mathrm{p}_{4}$ are proportionality constants for the decreasing second, third, and fourth phase; $c_{1}$ is the time of maximum increase for the increasing first phase (- - ), and $c_{\max 2}, c_{3}, c_{\max 4}$ are times of maximum decrease for the decreasing second (- - ), third (- - ), and fourth (- - -) phase.

\section{General Biological Model}

It is our assertion that Equation [7] describes the lactation curve as a multiphasic function, with an increasing first phase of milk yield and a series of decreasing phases of yield (Figure 1). The increasing phase, described by an increasing function of time $t$, models the increase in milk yield associated with a net increase in number of mammary gland cells and an increase in yield per cell. The decreasing phases, described by a sum of three decreasing functions of time, models decrease in milk yield associated with decrease in cell number due to apoptosis and decrease in yield per cell due to pregnancy in late lactation.

Mammary gland growth. Growth of the mammary gland during pregnancy, as measured by total DNA, is described best by an increasing exponential function of time in dairy heifers (Swanson and Poffenbarger, 1979), in goats (Anderson et al., 1981), and in several other mammalian species, including cows (Sheffield and Anderson, 1985). Primary cause of this exponential growth of the mammary gland during pregnancy is probably increase and synchronous secretion of estrogens and progesterone (Tucker, 1987).

After parturition, growth of the mammary gland in goats continues into early lactation, peaking at $5 \mathrm{~d}$ (Anderson et al., 1981), and even into the first $3 \mathrm{wk}$ of lactation (Knight and Peaker, 1984; Knight and Wilde, 1987). During early lactation, mammary cell numbers continue to increase. In cattle, there was a $65 \%$ increase in mammary cell numbers between $10 \mathrm{~d}$ prepartum and $10 \mathrm{~d}$ postpartum (Tucker, 1987).

These findings are consistent with findings that mammary gland growth in the accelerating part of the 
first phase of milk yield is completed by parturition, and that mammary gland growth in the decelerating part is completed after parturition (Swanson and Poffenbarger, 1979; Anderson et al., 1981; Sheffield and Anderson, 1985). Findings are also consistent with the process of lactogenesis, which occurs in two stages: stage I during gestation and stage II at parturition (Collier, 1999).

We modeled the increasing first phase of milk yield, therefore, as a linear logistic function of DIM:

$$
\frac{\mathrm{a}_{1}}{1+\mathrm{e}^{-\left(\mathrm{DIM}-\mathrm{c}_{1}\right) / \mathrm{b}_{1}}},
$$

where $a_{1}$ is upper asymptotic level of milk yield $(\mathrm{kg})$, $c_{1}$ is time of maximum increase $(d)$, and $b_{1}$ is proportional to duration of the increasing phase (d). The increasing logistic function was one of several alternative functions used by Rook et al. (1993) and was used also by Pollott (2000) to model increase in daily milk yield.

Apoptosis. Apoptosis, or programmed cell death, occurs when the cell either receives a death signal or loses a survival signal (Li et al., 1997; Terranova and Taylor, 1999). Apoptosis is part of normal animal development (Jacobson et al., 1997; Meier et al., 2000) and is a normal physiological event in the mammary gland of ruminants (Wilde et al., 1997; Knight, 2000; Capuco et al., 2001; Wareski et al., 2001).

Rate of growth of the mammary gland after parturition decreases during the increasing phase of milk yield, which means that growth of the mammary gland is limited. Mammary gland cell numbers during lactation, furthermore, eventually decline as milk yield declines (Tucker, 1987). In goats, apoptosis may be the principal cause of decrease in number of mammary gland secretory cells, and consequent decrease in milk yield, after the peak (Wareski et al., 2001) and into the declining stage of lactation (Wilde et al., 1997). A 40\% decline in milk yield, for example, was accompanied by a $40 \%$ decline in tissue DNA content (Wilde et al., 1997).

Mammary gland involution in mice is partly the result of increased apoptosis occurring in a two-stage process (Terranova and Taylor, 1999). Within hours after weaning in mice, apoptosis during mammary gland involution goes through two distinct stages ( $\mathrm{Li}$ et al., 1997): the first stage is progressive gain of local mammary-derived death signals and the second is loss of systemic hormonally-stimulated survival factors. The critical time for reversal of the first stage is during the first $48 \mathrm{~h}$ of involution (Li et al., 1997).

Mammary apoptosis occurs in goats and cows (Wilde et al., 1997). We might expect, therefore, by analogy to mice, that decrease in milk yield after the peak in cows as a result of apoptosis is also a two-stage process.
The first stage of relatively short duration, early in lactation, is the sudden loss of mammary cells, which might be due to gain in death signals soon after the peak. The second stage of relatively long duration, later in lactation, is the slower, more progressive loss of mammary cells, which might be due to loss of survival factors later after the peak. We assumed that the two stages of apoptosis were asymmetric because they must be sustained throughout lactation and into the dry period to prepare the mammary gland for the next lactation.

We modeled the decreasing second phase of milk yield (first stage of apoptosis) and the decreasing fourth phase of milk yield (second stage of apoptosis), therefore, each as a quadratic logistic function of DIM:

$$
\begin{aligned}
& -\frac{\mathrm{p}_{2} \mathrm{a}_{1}}{\left(1+0.5 \mathrm{e}^{\left.-\left(\mathrm{DIM}-\mathrm{c}_{\max 2}\right) / \mathrm{b}_{2}\right)^{2}}\right.} \\
& -\frac{\mathrm{p}_{4} \mathrm{a}_{1}}{\left(1+0.5 \mathrm{e}^{-\left(\mathrm{DIM}-\mathrm{c}_{\max 4} / \mathrm{b}_{4}\right)^{2}}\right.}
\end{aligned}
$$

where for the second decreasing phase, $\mathrm{p}_{2}$ is the decrease proportional to $a_{1}, b_{2}$ is proportional to duration (d), and $c_{\max 2}$ is time of maximum decrease (d); and where for the fourth decreasing phase, $p_{4}$ is the decrease proportional to $a_{1}, b_{4}$ is proportional to duration (d), and $\mathrm{c}_{\max 4}$ is time of maximum decrease $(\mathrm{d})$.

Pregnancy. Whereas decline in milk yield after the peak is associated primarily with decline in cell numbers due to apoptosis (Knight and Wilde, 1993), decline in milk yield during pregnancy is associated primarily with decline in milk synthesis and rate of secretion accompanying the increase in progesterone (Forsyth, 1999). The distinct decrease in milk yield occurs at about 5 or 6 mo of gestation (Schmidt, 1971; Coulon et al., 1995).

In cows early in pregnancy, the progesterone concentration curve appears to be diphasic over time: increasing during 3 to $12 \mathrm{~d}$ after mating, leveling off until about $30 \mathrm{~d}$, and increasing further to $39 \mathrm{~d}$ (Henricks et al., 1972). In cows later in pregnancy, however, progesterone levels tend to level off after about $50 \mathrm{~d}$ of gestation and to decline after about $250 \mathrm{~d}$ to undetectable levels at parturition (Gomes and Erb, 1965; Erb et al., 1968).

We modeled the decreasing third phase in milk yield (pregnancy), therefore, as a linear logistic function of DIM:

$$
-\frac{\mathrm{p}_{3} \mathrm{a}_{1}}{1+\mathrm{e}^{-\left(\mathrm{DIM}-\mathrm{c}_{3}\right) / \mathrm{b}_{3}},}
$$

where $p_{3}$ is the decrease proportional to $a_{1}, b_{3}$ is proportional to duration (d), and $c_{3}$ is time of maximum decrease $(d)$. 
The final model for the multiphasic lactation curve (Figure 1) was the sum of Equations [8] through [10]:

$$
\begin{gathered}
\mathrm{y}_{\text {DIM }}=\frac{\mathrm{a}_{1}}{1+\mathrm{e}^{-\left(\mathrm{DIM}-\mathrm{c}_{1}\right) / \mathrm{b}_{1}}}-\frac{\mathrm{p}_{2} \mathrm{a}_{1}}{\left(1+0.5 \mathrm{e}^{-\left(\mathrm{DIM}-\mathrm{c}_{\max 2}\right) / \mathrm{b}_{2}}\right)^{2}} \\
-\frac{\mathrm{p}_{3} \mathrm{a}_{1}}{1+\mathrm{e}^{-\left(\mathrm{DIM}-\mathrm{c}_{3}\right) / \mathrm{b}_{3}}}-\frac{\mathrm{p}_{4} \mathrm{a}_{1}}{\left(1+0.5 \mathrm{e}^{\left.-\left(\mathrm{DIM}-\mathrm{c}_{\max 4}\right) / \mathrm{b}_{4}\right)^{2}},\right.}
\end{gathered}
$$

where $\mathrm{y}_{\text {DIM }}$ is milk yield at each DIM and $\mathrm{p}_{4}=\left(1-\mathrm{p}_{2}\right.$ $-\mathrm{p}_{3}$ ). Note that total milk yield to Day T can be computed by integrating Equation [11] from 0 to T, because each term has a known integral.

\section{Data}

Data from 3573 first-lactation Holsteins were provided by the Universidad Nacional de Costa Rica (Vargas et al., 2000). Lactations were grouped into five classes by length in months (9 to 10,11 to 12,13 to 14 , 15 to 16 , and 17 to 18). Lactations also were grouped into five classes by open period, the interval in months from calving to conception during the current lactation ( 1 to 2,3 to 4,5 to 6,7 to 8 , and 9 to 10 ).

For this study, the five classes of lactation length in months were expressed at the midpoint in days $(\mathbf{L L})$ $(9.5 \mathrm{mo}=285 \mathrm{~d}, 11.5 \mathrm{mo}=345 \mathrm{~d}, 13.5 \mathrm{mo}=405 \mathrm{~d}, 15.5$ $\mathrm{mo}=465 \mathrm{~d}$, and $17.5 \mathrm{mo}=525 \mathrm{~d}$ ). Similarly, the five classes of open period in months were expressed at the midpoint in days open $(\mathbf{D O})(1.5 \mathrm{mo}=45 \mathrm{~d}, 3.5 \mathrm{mo}=$ $105 \mathrm{~d}, 5.5 \mathrm{mo}=165 \mathrm{~d}, 7.5 \mathrm{mo}=225 \mathrm{~d}$, and $9.5 \mathrm{mo}=$ $285 \mathrm{~d})$.

Groups with at least 1000 test-day records (12 of 25 possible groups) were retained for analysis. Each cow was required to have at least one test-day record in each of four periods: 1 to 60,61 to 150,151 to 240 , and 241 or more DIM. All test-day records after $305 \mathrm{~d}$ until the end of lactation were included. Test-day records within the 12 groups were classified by 2 -wk periods. For each period, average milk yield and DIM were computed and used for modeling (Vargas et al., 2000).

Result of groupings led to three classes of days carried calf while milking $(\mathbf{D C C}=\mathrm{LL}-\mathrm{DO})$ : three groups with 120 DCC, four with 180 DCC, and five with 240 DCC. The three groups with 120 DCC were, however, deleted for having too few days carried calf. The nine remaining groups, four with 180 DCC and five with 240 DCC, were retained for analysis. For those nine groups, average milk yield and DIM are in Table 1, by days carried calf, lactation length, and days open.

\section{Statistical Analysis}

Nonlinear regression (NLREG; Sherrod, 2000) was used to fit average milk yield for each of the nine data sets (Table 1), using Equation [11]. The convergence criterion for the iterative nonlinear estimation procedure was set at $1 \times 10^{-10}$. Goodness-of-fit criteria were adjusted $R^{2}$, residual $\mathrm{SE}$, and Durbin-Watson statistic (D-W). Values for D-W around 2 indicate lack of firstorder autocorrelation (Neter et al., 1985).

In addition, a simple linear regression analysis of each parameter estimate on LL within DCC was performed to test the hypothesis that the estimate is independent of LL (or equivalently DO).

\section{RESULTS AND DISCUSSION}

\section{Expectation of Model Parameters}

The upper level of milk yield for the first phase $\left(a_{1}\right)$ depends on many factors, such as breed or management, but it is not expected to depend on lactation length or days open. Growth of the mammary gland occurs to a greater extent during gestation and to a lesser extent after calving. Maximum increase in milk yield $\left(c_{1}\right)$, therefore, is expected before calving. Assuming that gestation period in dairy cattle is about $280 \mathrm{~d}$ (McDonald, 1971) and that growth of the mammary gland continues to about $60 \mathrm{~d}$ after parturition, then duration of the increasing phase $\left(10.88 b_{1}\right)$ is expected to be at most about $340(=280+60) \mathrm{d}$; hence $10.88 \mathrm{~b}_{1}$ $\leq 340$, so that $b_{1}$ is expected to be at most about $30 \mathrm{~d}$.

Decrease in milk yield during the second phase (first phase of apoptosis around peak yield), expressed as a proportion $\left(\mathrm{p}_{2}\right)$ of $\mathrm{a}_{1}$, is expected to be relatively small (Wareski et al., 2001). Duration of the second phase $\left(10.88 \mathrm{~b}_{2}\right)$ is expected to be relatively short ( $\mathrm{Li}$ et al., 1997). Maximum decrease $\left(\mathrm{c}_{\max 2}\right)$ is expected after peak milk yield.

Decrease in milk yield during the third phase (pregnancy), expressed as a proportion $\left(\mathrm{p}_{3}\right)$ of $\mathrm{a}_{1}$, is expected to be relatively large (Coulon et al., 1995). Duration of the third phase $\left(10.88 \mathrm{~b}_{3}\right)$ is expected to be about $280 \mathrm{~d}$ (the gestation period); hence $b_{3}$ is expected to be about $25 \mathrm{~d}$. The effect of progesterone during pregnancy on decrease in milk yield can be seen by about $150 \mathrm{~d}$ of gestation (Schmidt, 1971; Coulon et al., 1995). This finding is consistent with findings in cows whose concentration of progesterone in blood reached relatively high levels by about $130 \mathrm{~d}$ after pregnancy (Gomes and Erb, 1965). This means that for an open period of 45 $\mathrm{d}$, for example, maximum decrease in milk yield $\left(\mathrm{c}_{3}\right)$ is expected by about $195(=45+150) \mathrm{d}$; for an open period of $105 \mathrm{~d}$, by about $255(=105+150) \mathrm{d}$; and for an open period of $285 \mathrm{~d}$, by about $435(=285+150) \mathrm{d}$. Values for $\mathrm{c}_{3}$ therefore, are expected to increase as days open increases.

Decrease in milk yield during the fourth phase (second phase of apoptosis), expressed as a proportion ( $\mathrm{p}_{4}$ 
Table 1. Average milk yield (kg) and days in milk (DIM) by days carried calf, lactation length, and days open.



${ }^{1}$ Source: Bernardo Vargas Leitón, Universidad Nacional, Costa Rica.

$=1-\mathrm{p}_{2}-\mathrm{p}_{3}$ ) of $\mathrm{a}_{1}$, is expected to be relatively large (Wareski et al., 2001). Duration of the fourth phase $\left(10.88 \mathrm{~b}_{4}\right)$ is expected to be relatively long, extending beyond the end of lactation, into the dry period. Assuming that a standard lactation length is about $285 \mathrm{~d}$ and that dry period following the end of lactation is about $60 \mathrm{~d}$, for example, one would expect this fourth phase to be sustained for about $345(=285+60) \mathrm{d}$ after calving; hence $b_{4}$ would be about $32 \mathrm{~d}$. For an extended lactation length of about $525 \mathrm{~d}$; however, this phase would be sustained for about $585(=525+60)$ d after calving; hence $\mathrm{b}_{4}$ would be about $54 \mathrm{~d}$. Maximum decrease in milk yield $\left(c_{\max 4}\right)$ is expected late in lactation. Values for $b_{4}$ and $c_{\max 4}$, therefore, are expected to increase as lactation length increases.

\section{Estimates of Model Parameters}

Estimates of model parameters and goodness-of-fit criteria, by lactation length (LL) within days carried calf (DCC); means of parameter estimates; and estimates of regression $(\beta)$ of parameter estimates on LL within DCC are in Table 2. Goodness-of-fit criteria indicated that the model fit the data well: $R^{2}$ was about 
Table 2. Estimates of mode ${ }^{1}$ parameters, adjusted $\mathrm{R}^{2}$, residual SE (RSE), and Durbin-Watson statistic (D-W), by lactation length (LL, d) within days carried calf (DCC); means of parameter estimates; and estimates of regression ( $\beta$ ) of parameter estimates on LL within DCC.

\begin{tabular}{|c|c|c|c|c|c|c|c|c|c|c|c|c|c|c|c|}
\hline $\mathrm{LL}$ & \multicolumn{12}{|c|}{ Parameter } & \multicolumn{3}{|c|}{ Goodness-of-fit } \\
\hline \multicolumn{16}{|c|}{$\mathrm{DCC}=180$} \\
\hline 345 & 22.34 & 9.94 & -8.04 & 0.06 & 4.71 & 83.65 & 0.46 & 73.95 & 252.33 & 0.48 & 26.17 & 364.10 & 0.994 & 0.283 & 2.40 \\
\hline 405 & 20.40 & 11.60 & -14.20 & 0.30 & 59.79 & 96.85 & -0.09 & 12.47 & 360.69 & 0.80 & 62.75 & 394.93 & 0.993 & 0.271 & 2.74 \\
\hline 465 & 21.89 & 8.10 & $-8.50^{b}$ & 0.26 & 48.58 & 122.97 & -0.06 & 7.74 & 370.15 & 0.80 & 70.99 & 446.75 & 0.991 & 0.365 & 2.43 \\
\hline \multicolumn{16}{|c|}{$\mathrm{DCC}=240$} \\
\hline 285 & 1.76 & 9.72 & -7.22 & 0.13 & 14.61 & 104.22 & 0.07 & 10.40 & 178.06 & 0.80 & 41.09 & 286.30 & 0.984 & 0.496 & 2.91 \\
\hline 345 & 23.05 & 12.21 & -11.39 & 0.25 & 53.56 & 118.78 & -0.02 & 12.46 & 249.28 & 0.77 & 56.28 & 336.54 & 0.994 & 0.316 & 2.62 \\
\hline 405 & 21.91 & 7.10 & -3.60 & 0.13 & 23.19 & 98.61 & 0.09 & 18.04 & 215.34 & 0.78 & 55.74 & 390.70 & 0.995 & 0.256 & 1.94 \\
\hline 465 & 22.10 & 10.38 & -7.41 & 0.18 & 30.56 & 122.76 & -0.04 & 8.48 & 327.61 & 0.86 & 82.08 & 424.11 & 0.985 & 0.519 & 2.95 \\
\hline 525 & 21.59 & 18.53 & -27.31 & 0.09 & 9.84 & 91.97 & 0.05 & 6.31 & 467.09 & 0.86 & 237.14 & 501.72 & 0.992 & 0.277 & 2.71 \\
\hline Mean & 22.08 & 11.59 & -11.39 & 0.16 & 26.35 & 107.27 & 0.03 & 11.14 & 287.47 & 0.81 & 94.47 & 387.87 & & & \\
\hline
\end{tabular}

${ }^{\mathrm{a} C o m p u t e d}$ as $1-\mathrm{p}_{2}-\mathrm{p}_{3}$.

${ }^{\mathrm{b}}$ Set as a constant for convergence.

$$
\begin{aligned}
& 1_{\mathrm{dim}}=\frac{\mathrm{a}_{1}}{1+\mathrm{e}^{-\left(\mathrm{DIM}-\mathrm{c}_{1}\right) / \mathrm{b}_{1}}}-\frac{\mathrm{p}_{2} \mathrm{a}_{1}}{\left(1+0.5 \mathrm{e}^{\left.-\left(\mathrm{DIM}-\mathrm{c}_{\max 2}\right) / \mathrm{b}_{2}\right)^{2}}\right.}-\frac{\mathrm{p}_{3} \mathrm{a}_{1}}{1+\mathrm{e}^{-\left(\mathrm{DIM}-\mathrm{c}_{3}\right) / \mathrm{b}_{3}}}-\frac{\left(1-\mathrm{p}_{2}-\mathrm{p}_{3}\right) \mathrm{a}_{1}}{\left(1+0.5 \mathrm{e}^{-\left(\mathrm{DIM}-\mathrm{c}_{\max 4} / \mathrm{b}_{4}\right)^{2}} .\right.} \\
& * 0.05 \leq P \leq 0.10, * * P \leq 0.01, * * * P \leq 0.001 .
\end{aligned}
$$

0.99 , residual SE was between about 0.14 and 0.52 , and $\mathrm{D}-\mathrm{W}$ was between about 1.9 and 3.2. Recall that a value around 2 for D-W indicates a lack of first-order autocorrelation. Parameter estimates within DCC did not change as LL, or equivalently DO, increased, except for $\mathrm{c}_{3}, \mathrm{~b}_{4}$, and $\mathrm{c}_{\max 4}$, as expected. Observed and predicted milk yield are in Figures 2 and 3 for DCC $=180$ and in Figures 4 and 5 for DCC $=240$.

Average results for DCC $=180$ and DCC $=240$ (Table 2 ) indicated that for the increasing first phase, upper level of milk yield $\left(\mathrm{a}_{1}\right)$ was about $22 \mathrm{~kg}$. Duration $\left(10.88 b_{1}\right)$ was about $120 \mathrm{~d}$, within expectation, centered on time of maximum increase $\left(c_{1}\right)$, which was about 11



Figure 2. For days carried calf while milking $=180$, actual milk yield for lactation lengths of $285 \mathrm{~d}(-), 345 \mathrm{~d}(---), 405 \mathrm{~d}(---)$, and $465 \mathrm{~d}(---)$. $\mathrm{d}$ before calving. This means that the decelerating part of the increasing phase of milk yield began before calving and was sustained for about $49[=-11+1 / 2(120)] d$ after calving, as expected. These findings are consistent with other results of modeling that suggest that increase in cell number is already decelerating at calving (Rook et al., 1993). Level of yield, duration, and time of maximum increase did not change as LL or DO increased, as expected, because cows were not yet pregnant nor dried off.

For the second phase (first phase of apoptosis), decrease in milk yield $\left(\mathrm{p}_{2}\right)$ was relatively large (about $20 \%$ of $\mathrm{a}_{1}$ ) and duration $\left(10.88 \mathrm{~b}_{2}\right.$ ) was relatively long (about

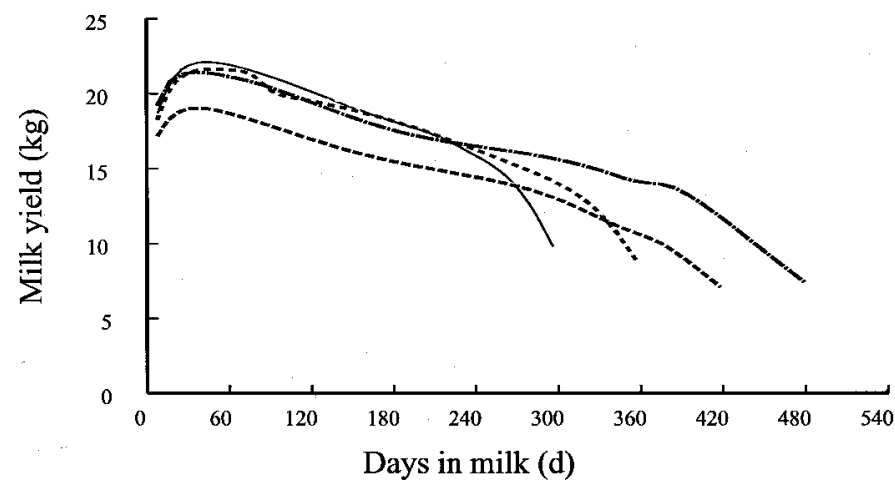

Figure 3. For days carried calf while milking $=180$, predicted milk yield for lactation lengths of $285 \mathrm{~d}$ (-), $345 \mathrm{~d}(---), 405 \mathrm{~d}$ (- - -), and $465 \mathrm{~d}(---)$. 


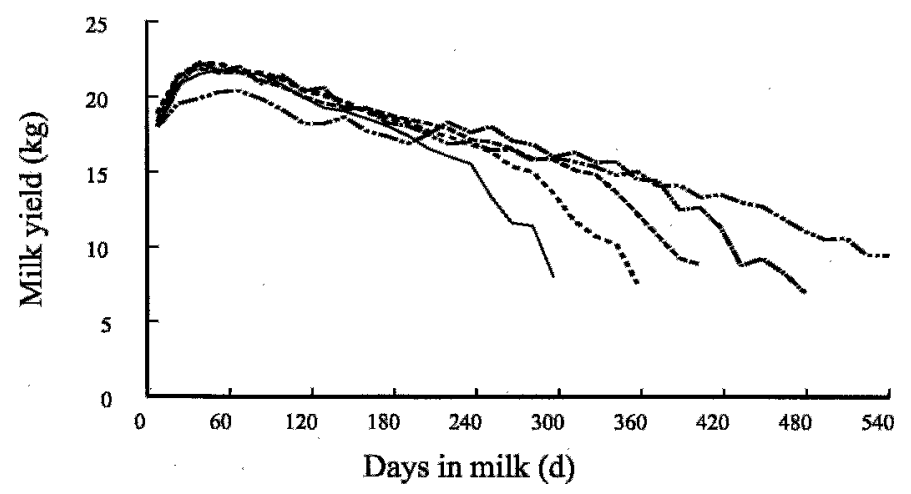

Figure 4. For days carried calf while milking $=240$, actual milk yield for lactation lengths of $285 \mathrm{~d}(-), 345 \mathrm{~d}(---), 405 \mathrm{~d}(---)$, $465 \mathrm{~d}(---)$, and $525 \mathrm{~d}\left(---_{-}\right)$.

$375 \mathrm{~d})$. For $\mathrm{LL}=525$, however, decrease was relatively small and duration was relatively short, as expected (Li et al., 1997; Wareski et al., 2001). Time of maximum decrease $\left(\mathrm{c}_{\max 2}\right)$ was about $107 \mathrm{~d}$ after calving, which is after peak yield. This means that the first phase of apoptosis started at about 60 [= $107-0.44$ (375)] d before calving, which helps explain why growth of the mammary gland is limited to an upper level, and hence why the increasing first phase of milk yield is also limited. Level of decrease, duration, and time of maximum decrease did not change as LL or DO increased, as expected.

For the third phase (pregnancy), decrease in milk yield $\left(\mathrm{p}_{3}\right)$ was relatively small (about $6 \%$ of $\mathrm{a}_{1}$ ) and duration $\left(10.88 \mathrm{~b}_{3}\right)$ was relatively short (about $200 \mathrm{~d}$ ). Time of maximum decrease $\left(c_{3}\right)$ was about $300 \mathrm{~d}$ after calving. For each additional day open, time of maximum decrease increased $(\beta)$ about $1 \mathrm{~d}$, as expected. For DO $=105(\mathrm{DCC}=180, \mathrm{LL}=285 ; \mathrm{DCC}=240, \mathrm{LL}=345)$, for example, maximum decrease in milk yield was by about $255(=105+150) \mathrm{d}$ after calving, whereas for DO $=285$ $(\mathrm{DCC}=180, \mathrm{LL}=245 ; \mathrm{DCC}=240, \mathrm{LL}=525)$, for example, maximum decrease was by about $435(=285+150)$ $\mathrm{d}$ after calving.

For the fourth phase (second phase of apoptosis), decrease in milk yield $\left(\mathrm{p}_{4}=1-\mathrm{p}_{2}-\mathrm{p}_{3}\right)$ was relatively large (about $74 \%$ of $\mathrm{a}_{1}$ ) and duration $\left(10.88 \mathrm{~b}_{4}\right)$ was relatively long (about $765 \mathrm{~d}$ ). For $\mathrm{LL}=525$, duration was exceptionally long. Time of maximum decrease $\left(c_{\max 4}\right)$ was about $382 \mathrm{~d}$ after calving. For each additional day of lactation, duration increased $(\beta)$ about $5.4[=0.5 \times$ 10.88] $\mathrm{d}$ and day of maximum decrease increased $(\beta)$ about $0.82 \mathrm{~d}$. These results might be expected because cows were being dried off to prepare the mammary gland for the next parturition.

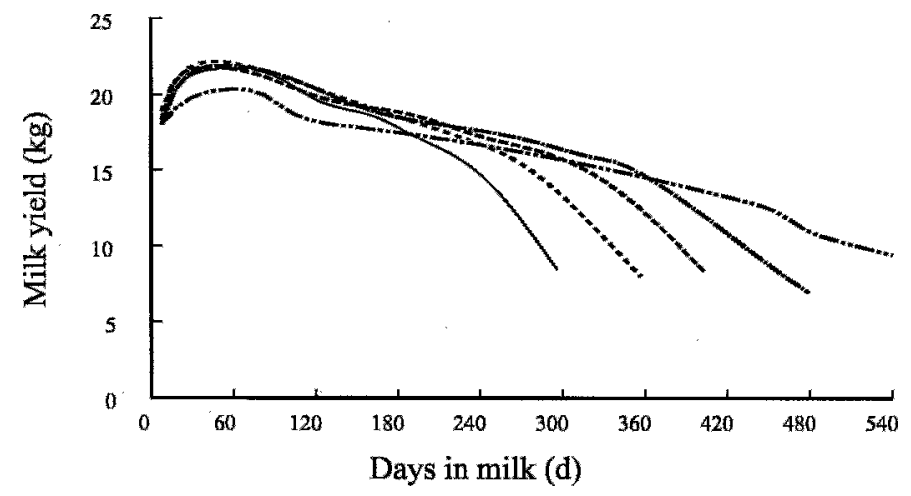

Figure 5. For days carried calf while milking $=240$, predicted milk yield for lactation lengths of $285 \mathrm{~d}$ (- $-345 \mathrm{~d}(---), 405 \mathrm{~d}$ $(---), 465 \mathrm{~d}(---)$, and $525 \mathrm{~d}(----)$.

\section{CONCLUSIONS}

Objectives of this study were to describe the biological basis for multiphase milk yield and to propose a new empirical model for the lactation curve, based on biological theory and predicated on the multiphasic approach for use with standard and extended lactations.

We achieved the first objective by reviewing briefly the biological relation between the general shape of the lactation curve and changes in cell number and function of the mammary gland. Although milk yield starts at parturition, yield is associated with net increase in cell numbers as the mammary gland grows during gestation and into early lactation. Yield rises rapidly to a peak as secretion rate increases, maintains a level for a period of time, and then decreases until the end of lactation as cell number decreases due to apoptosis and as secretion rate decreases due to pregnancy.

We achieved the second objective by describing the lactation curve empirically using a multiphasic approach. Starting with the diphasic function (Grossman and Koops, 1988), which has proved itself useful to describe lactation curves for sheep (Pollott and Gootwine, 2000), goats (Gipson and Grossman, 1989), and cows (Sherchand et al., 1995; Vargas et al., 2000), we expanded and reparameterized the function so that it contained an increasing phase of milk yield and a series of three decreasing phases of yield. Increase in milk yield, associated with net increase in number of mammary cells and increase in yield per cell, was modeled by an increasing linear logistic function of days in milk. Decrease in milk yield, associated with decrease in cell number due to apoptosis and decrease in yield per cell due to pregnancy in late lactation, was modeled by a sum of decreasing linear and quadratic logistic functions of days in milk. We illustrated this model using nine datasets for standard and extended lactations of 
various lengths (285 to $525 \mathrm{~d}$ ) and various days open (45 to $285 \mathrm{~d})$.

One uncertainty with this study was that the extended lactations were unplanned, so that some lactations could be longer than standard because of reproductive problems; hence the various classes of days open. Lactations, therefore, were grouped into two classes of DCC, one for $180 \mathrm{~d}$ and one for $240 \mathrm{~d}$. For DCC $=180$, it was more difficult to separate the effect on milk yield of apoptosis from the effect of pregnancy, because the two effects were probably confounded. This is seen clearly for estimates of $p_{2}$ and $b_{2}$ for the first apoptosis phase and of $\mathrm{p}_{3}$ and $\mathrm{b}_{3}$ for the pregnancy phase. For each of the two phases, average decrease and duration for DCC $=180$ were about $50 \%$ more than those for $\mathrm{DCC}=240$. Phases of relatively short duration, e.g., the second and third phases for DCC $=240$ and $\mathrm{LL}=525$, make it easier to separate confounded effects, especially if the maximum effects of these phases are widely separated, about $90 \mathrm{~d}$ for $\mathrm{c}_{\max 2}$ compared with about $460 \mathrm{~d}$ for $\mathrm{c}_{3}$.

A limitation to this research was that we asserted an association between a biological event and a phase of the multiphasic lactation curve. The assertion was based on "circumstantial evidence" from the literature and not on direct evidence. Nevertheless, the preponderance of evidence for a multiphasic lactation curve seems incontrovertible, and it remains for future research to establish a direct association between a specific biological event and a specific phase of the lactation curve.

We conclude, therefore, that it is possible to empirically model the lactation curve of dairy cows, based on biological theory and predicated on the multiphasic approach. Further research to understand better the biology of extended lactations, using the proposed multiphasic model, should use planned extended lactations that are at least 525 DIM and have at least 240 days carried calf.

\section{ACKNOWLEDGMENTS}

The School of Veterinary Medicine, Population Medicine Programme, Universidad Nacional, Costa Rica provided data for this study, through the kindness of Dr. Bernardo Vargas Leitón. The Animal Production Systems Group at Wageningen University generously provided M. G. an opportunity to conduct this research while on sabbatical leave.

\section{REFERENCES}

Anderson, R. R., J. R. Harness, A. F. Snead, and M. S. Salah. 1981. Mammary growth pattern in goats during pregnancy and lactation. J. Dairy Sci. 64:427-432.
Beever, D. E., A. J. Rook, J. France, M. S. Dhanoa, and M. Gill. 1991. A review of empirical and mechanistic models of lactational performance by the dairy cow. Livest. Prod. Sci. 29:115-130.

Bertilsson, J., B. Berglund, G. Ratnayake, K. Svennersten-Sjaunja, and $\mathrm{H}$. Wiktorsson. 1997. Optimising lactation cycles for the highyielding dairy cow. A European perspective. Livest. Prod. Sci. 50:5-13.

Bock, R. D. 1975. Multivariate Statistical Methods in Behavioral Research. McGraw-Hill, Inc., New York, NY.

Capuco, A. V., D. L. Wood, R. Baldwin, K. Mcleod, and M. J. Paape. 2001. Mammary cell number, proliferation, and apoptosis during a bovine lactation: Relation to milk production and effect of bST. J. Dairy Sci. 84:2177-2187.

Collier, R. J. 1999. Lactation, nonhuman. Pages 973-979 in Encyclopedia of Reproduction. E. Knobil and J. D. Neill, ed. Academic Press, New York, NY.

de Boer, J. A., J. I. Weller, T. A. Gipson, and M. Grossman. 1989. Multiphasic analysis of milk and fat yield curves of Israeli Holsteins. J. Dairy Sci. 72:2143-2152.

Coulon, J. B., L. Pérochon, and F. Lescourret. 1995. Modelling the effect of the stage of pregnancy on dairy cows' milk yield. Anim. Sci. 60:401-408.

Dijkstra, J., J. France, M. S. Dhanoa, J. A. Maas, M. D. Hanigan, A. J. Rook, and D. E. Beever. 1997. A model to describe growth patterns of the mammary gland during pregnancy and lactation. J. Dairy Sci. 80:2340-2354.

Erb, R. E., V. L. Estegreen, Jr., W. R. Gomes, E. D. Plotka, and O. L. Frost. 1968. Progestin levels in corpora lutea and progesterone in ovarian venous and jugular vein blood plasma of the pregnant bovine. J. Dairy Sci. 51:401-410.

FAWC. 1997. Report on the Welfare of Dairy Cattle. The Farm Animal Welfare Council, The Ministry of Agriculture, Fisheries and Food, London, UK. http://www.maff.gov.uk/animalh/welfare/fawc/ dairycow/DCOWR075.htm . Accessed 27 Feb. 2001.

Forsyth, I. 1999. Mammary gland, overview. Pages 81-88 in Encyclopedia of Reproduction. E. Knobil and J. D. Neill, ed. Academic Press, New York, NY.

Gipson, T. A., and M. Grossman. 1989. Diphasic analysis of lactation curves in dairy goats. J. Dairy Sci. 72:1035-1044.

Gipson, T. A., and M. Grossman. 1990. Lactation curves in dairy goats: A review. Small Rumin. Res. 3:383-396.

Gomes, W. R., and R. E. Erb. 1965. Progesterone in bovine reproduction: A review. J. Dairy Sci. 48:314-330.

Grossman, M., S. M. Hartz, and W. J. Koops. 1999. Persistency of lactation yield: A novel approach. J. Dairy Sci. 82:2192-2197.

Grossman, M., and W. J. Koops. 1988. Multiphasic analysis of lactation curves in dairy cattle. J. Dairy Sci. 71:1598-1608.

Gupta, S. S., and M. Gnanadesikan. 1966. Estimation of the parameters of the logistic distribution. Biometrika 53:565-570.

Henricks, D. M., J. F. Dickey, J. R. Hill, and W. E. Johnston. 1972. Plasma estrogen and progesterone levels after mating, and during late pregnancy and postpartum in cows. Endocrinology 90:1336-1342.

Jacobson, M. D., M. Weil, and M. C. Raff. 1997. Programmed cell death in animal development. Cell 88:347-354.

Knight, C. H. 1997. Biological control of lactation length. Livest. Prod. Sci. 50:1-3.

Knight, C. H. 1998. Extended lactation. Pages 30-39 in Yearbook, Hannah Research Institute, Ayr, Scotland, UK.

Knight, C. H. 2000. The importance of cell division in udder development and lactation. Livest. Prod. Sci. 66:169-176.

Knight, C. H., and M. Peaker. 1984. Mammary development and regression during lactation in goats in relation to milk secretion. Q. J. Exp. Physiol. 69:331-338.

Knight, C. H., and A. Sorensen. 2000. Manipulation of lactation persistency with maintenance of milk quality. J. Dairy Sci. 83(Suppl. 1):24.

Knight, C. H., and C. J. Wilde. 1987. Mammary growth during lactation: Implications for increasing milk yield. J. Dairy Sci. 70:1991-2000.

Knight, C. H., and C. J. Wilde. 1993. Mammary cell changes during pregnancy and lactation. Livest. Prod. Sci. 35:3-19. 
Li, M., X. Liu, G. Robinson, U. Bar-Peled, K.-U. Wagner, W. S. Young, L. Hennighausen, and P. A. Furth. 1997. Mammary-derived signals activate programmed cell death during the first stage of mammary gland involution. Proc. Natl. Acad. Sci. (Physiol.) 94:3425-3430.

McDonald, L. E. 1971. Page 347 in Veterinary Endocrinology and Reproduction. Lea \& Febiger, Philadelphia, PA.

Meier, P., A. Finch, and G. Evan. 2000. Apoptosis in development. Nature 407:796-801.

Neal, H. D. St. C., and J. H. M. Thornley. 1983. The lactation curve in cattle: a mathematical model of the mammary gland. J. Agric. Sci. (Camb.) 101:389-400.

Neter, J., W. Wasserman, and M. H. Kutner. 1985. Applied Linear Statistical Models. 2nd ed. Richard D. Irwin, Inc., Homewood, IL.

Oldham, J. D., and G. C. Emmans. 1989. Prediction of responses to required nutrients in dairy cows. J. Dairy Sci. 72:3212-3229.

Pollott, G. E. 2000. A biological approach to lactation curve analysis for milk yield. J. Dairy Sci. 83:2448-2458.

Pollott, G. E., and E. Gootwine. 2000. Appropriate mathematical models for describing the complete lactation of dairy sheep. Anim. Sci. 71:197-207.

Rook, A. J., J. France, and M. S. Dhanoa. 1993. On the mathematical description of lactation curves. J. Agric. Sci. 121:97-102.

Ruiz, R. L., M. Oregui, and M. Herrero. 2000. Comparison of models for describing the lactation curve of Latxa sheep and an analysis of factors affecting milk yield. J. Dairy Sci. 83:2709-2719.

Schmidt, G. H. 1971. Biology of Lactation. W. H. Freeman and Co., San Francisco, CA.

Sheffield, L. G., and R. R. Anderson. 1985. Interspecies variation in mammary gland growth rate: Relationship to gestation length. J. Dairy Sci. 68:2571-2579.

Sherchand, L., R. W. McNew, D. W. Kellogg, and Z. B. Johnson. 1995. Selection of a mathematical model to generate lactation curves using daily milk yields of Holstein cows. J. Dairy Sci. 78:25072513.

Sherrod, P. H. 2000. Nonlinear Regression Analysis Program, NLREG Version 5.0 Phillip H. Sherrod, Nashville, TN.

Swanson, E. W., and J. I. Poffenbarger. 1979. Mammary gland development of dairy heifers during their first gestation. J. Dairy Sci. 62:702-714.

Terranova, P. F., and C. C. Taylor. 1999. Apoptosis (cell death). Pages 261-273 in Encyclopedia of Reproduction. E. Knobil and J. D. Neill, ed. Academic Press, New York, NY.

Tozer, P. R., and R. G. Huffaker. 1999. Mathematical equations to describe lactation curves for Holstein-Friesian cows in New South Wales. Aust. J. Agric. Res. 50:431-440.

Tucker, H. A. 1987. Quantitative estimates of mammary growth during various physiological states: A review. J. Dairy Sci. 70:1958-1966.

van Amburgh, M. E., D. M. Galton, D. E. Bauman, and R. W. Everett. 1997. Management and economics of extended calving intervals with use of bovine somatotropin. Livest. Prod. Sci. 50:15-28.

Vargas, B., W. J. Koops, M. Herrero, and J. A. M. van Arendonk. 2000. Modeling extended lactations of dairy cows. J. Dairy Sci. 83:1371-1380.

Wareski, P., T. Motyl, Z. Ryniewicz, A. Orzechowski, B. Gajkowska, U. Wojewodzka, and T. Ploszaj. 2001. Expression of apoptosisrelated proteins in mammary gland of goat. Small Rumin. Res. 40:279-289.

Wilde, C. J., L. H. Quarrie, E. Tonner, D. J. Flint, and M. Peaker. 1997. Mammary apoptosis. Livest. Prod. Sci. 50:29-37.

Wilde, C. J., and C. H. Knight. 1989. Metabolite adaptations in mammary gland during the declining phase of lactation. J. Dairy Sci. 72:1679-1692.

Williams, J. C. 1993. An empirical model for the lactation curve of white British dairy goats. Anim. Prod. 57:91-97.

Wood, P. D. P. 1967. Algebraic model of the lactation curve in cattle. Nature (Lond.) 216:164-165. 